\title{
PERCEIVED OVERQUALIFICATION AS A DETERMINANT OF PROACTIVE BEHAVIOR AND CAREER SUCCESS: THE NEED FOR ACHIEVEMENT AS A MODERATOR
}

\author{
Sumaira Aslam ${ }^{1}$ Naeem Shahid ${ }^{2 *}$ and Abdul Sattar ${ }^{3}$
}

\begin{abstract}
Recent studies show the importance of overqualification for the career success of professionals. Drawing on relative deprivation and person-environment fit theory and with a focus on career success perspective, we examined the effect of perceived overqualification on career success via proactive behaviour and relative deprivation, and how the need for achievement moderates the relationship between perceived overqualification and proactive behaviour and relative deprivation. The study collected data in three waves using time lagged design from the top universities of Lahore and Faisalabad, Pakistan. In the first set of surveys, 456 questionnaires were returned, yielding an 85.23 percent response rate. Three hundred eighty-two questionnaires were returned in the second round of surveys, yielding an 83.77 percent response rate. In the third round of surveys, 318 questionnaires were received, accounting for 83.25 percent of the total. so a total of 318 questionnaires were selected for analysis. The study found that perceived overqualification was found to have a positive relationship with career success. Proactive behaviour and relative deprivation mediate between overqualification and career success. Moreover, the findings suggest that a high need for achievement strengthens the positive relationship between perceived overqualifications and proactive behaviour, whereas a high need for achievement weakens the relation between perceived overqualification and relative deprivation. These findings show that employees high on need for achievement will show more proactive behaviour with overqualification and low relative deprivation. The findings suggest many theoretical as well as practical implications for managers to reduce overqualification perceptions of employees in an organizational context. The managerial implications are also discussed in the end.
\end{abstract}

Keywords: Perceived Overqualification; Proactive Behavior; Relative Deprivation; Need for Achievement; Career Success; PE Fit Theory.

\footnotetext{
${ }^{1}$ Independent Researcher. Email: samas7480@yahoo.com

${ }^{2}$ Assistant Professor, Department of Business Administration, Institute of Arts and Sciences, Government College University Faisalabad, Chiniot Campus, Pakistan. Email: naeemtuf@yahoo.com

${ }^{3}$ Associate Professor, Department of Management Sciences, Bahria University Islamabad, Pakistan.

Email: abdulsattar_63@yahoo.com

*Corresponding Author
} 


\section{INTRODUCTION}

The Covid-19 pandemic situation has influenced the workers and organizations dramatically across the globe. Rudolph et al. (2021) identified most influencing factors in the field of industrial and organizational psychology like work-family issues, occupational health and safety, job insecurity, the aging workforce, human resources policy, virtual teamwork, telecommuting, leadership, precarious work, and career orientation. He also argued that although the pandemic situation is challenging but also offering multiple opportunities to the organizations. However, due to COVID, many people are concerned about their jobs and/or are directly affected by the pandemic situation and lost their jobs. Even if many who are employed working on positions for which they are overqualified. Howard and Luksyte (2021) discussed that the individuals over qualifying for their jobs have experienced two paths, one who did not lost their jobs during pandemic are feeling blessed to have even a poorly fit job rather than considering it as a curse. The second one's are those who lost their jobs during pandemic, can consider it an opportunity to find a new and better job. As Overqualification implies to the fact that a person with more knowledge, skills, and qualifications than they need for their job (e.g., Maynard et al., 2006). OECD in its current statistics (2021) reported that many countries are affected by this phenomenon and overqualification ratio is higher for COVID period e.g., Mexico (37.7\%), European Union (14.7\%), US (15.6\%), Spain (20\%) and $\mathrm{UK}(13.5 \%)$.

Overqualification is common in every organization's life. The footprints of prior overqualification research can be traced from organizational and work psychology, and its relevant disciplines, making the sense of many important implications for mangers and organizations. Mainly the relevant literature falls into tow streams (a) evolving shifts in work related organizational practices (for example, virtual teamwork; work from home) and (b) new patterns for employees (like, unemployment; increased stress; and social distancing). Moreover, few of potential moderators (e.g., individual differences; organizational norms; and demographic characteristics) are tested to observe the likelihood of COVID-19 on perceived overqualification and its significant organizational outcomes like the research suggests that employees with moderately positive perceptions about overqualification can contribute to the organizational success (Erdogan et al., 2011). Similarly, Erdogan, and Bauer (2021) argued that overqualification as an outcome consequence of a job attitude the factors other than job characteristics; personality and demographics, might be contributing to positive perceptions of overqualification. Person job fit and relative deprivation theory, the two main motivational theories can give some of consistent justifications about the negative effects of 
overqualification, while the capability-based theory illustrates the positive consequences of perceived overqualification.

\section{LITERATURE REVIEW}

Literature suggests two types of measures of overqualification, for instance, subjective measures (i.e., to what extent a person subjectively feels that they have more qualifications knowledge, and skills, than would be necessary for their job (Maynard et al., 2006). Operationalization of overqualification using objective measures often compares a person's qualification with requirement of job (e.g., Büchel \& Mertens, 2004). If the person's qualification exceeds the required one, it indicates overqualification. Another possibility is adding the number of years that a person has spent in school and further education with the number of years of training typically spent on a specific job - can be reached to compare. There are also comparative methods for determining objective overqualification. People are defined as overqualified if they have higher qualification than those people holding for the position on average (Hung, 2008). In social-scientific-psychological research, subjective assessment dominates because it is considered more relevant for those affected' attitudes and well-being (Erdogan et al., 2011). A current meta-analysis shows a medium-high correlation (sampleweighted, corrected $\rho=0.40$ ) between subjective and objective overqualification measures (Harari et al., 2017).

\section{Theoretical Explanations and Outcomes of Overqualification}

To predict overqualification and its outcomes, research is based primarily on two theories. Crosby's (1984) theory of relative deprivation explains that individuals develop certain expectations regarding their job based on their educational background, experience, and skills. They want to get a job where they can use their qualifications adequately. In case of failure of such expectation, people experience a feeling of deprivation, which is associated with frustration and anger. According to the theory, these emotional states culminate in unfavorable work attitudes (e.g., lower job satisfaction and less commitment to the organization).

The person-environment (PE) fit theory (e.g., Kristof-Brown et al., 2005; Van Harrison, 1978) assumes that people experience a high level of satisfaction and well-being, especially when they have a high qualifications than that required for job (e.g., demands-abilities fit) and needs and the offers of job (e.g., needs-supplies fit). If people are overqualified, they experience a mismatch of their qualifications and job's basic requirements. Researchers predicted unfavorable working attitudes, reduced well-being, and stronger intentions to change (see Harari et al., 2017). However, the PE Fit theory also points out that a situation of excess qualifications can also be positively associated with well-being and satisfaction, provided that 
people can use their excess qualifications in their work in other ways or if they have the opportunity to be able to conserve resources for later purposes (e.g., Edwards, 1996).

Regarding subjective overqualification, empirical studies mostly show negative correlation with different organizational outcomes. . The meta-analysis mentioned at the beginning (Harari et al., 2017) argued that overqualification is positively related to lower level of job satisfaction $(\rho=-0.41)$, less organizational commitment $(\rho=-0.35)$, less well-being $(\rho=-0.26)$ and a higher intent to change $(\rho=0.37)$ or increased job search behavior $(\rho=0.30)$. With regard to work performance, it was shown that overqualification goes hand in hand with a higher degree of counterproductive behavior (i.e., behavior with which people intentionally want to harm their work colleagues and the organization) $(\rho=0.16)$. Overqualification is also negatively related to self-reported voluntary work behavior $(\rho=-0.25)$; contrary to the study authors' expectations, however, there were no connections between the task-related work performance and creative or innovative behavior. So far, no meta-analyzes exist on the correlates of objective overqualification. However, primary studies indicate that the correlations are weaker or, in some cases, even insignificant (e.g., Hung, 2008).

\section{Overqualification and Career Success}

Career success describes the extent to which positive work-related consequences result from a person's work (see, Arthur et al., 2005). Subjective scale to examine the career success relate to attitudes and the subjective perception of one's career (Heslin, 2005); this includes perceived career success and career satisfaction. career success can be measured using its basic dimension like salary, salary development, and promotions achieved ( $\mathrm{Ng}$ et al., 2005).

There are only few studies that discuss the relationship between overqualification and subjective measures of career success. For a sample of university graduates from the United Kingdom, Nabi (2003) reports a negative correlation between subjective overqualification and career satisfaction. Lee (2005) comes to similar conclusions with expatriates working in Singapore. There are significantly more studies for objective measures of career success. Quintini (2011) reports a lower salary for objectively overqualified people than required for their current job in comparison to workers with the same qualifications but with an adequate job experience. However, if overqualified people are compared with workers who hold the same job but are well trained are getting higher salaries. According to a review by McGuinness in (2006) based on 21 individual studies (with both objective and subjective measures of overqualification), these losses amount to an average $15 \%$ lower salary for overqualified employees compared to suitably qualified employees. Mavromaras et al. (2010) come to a similar result with a purely subjective measure of overqualification: On the one hand, the British and Australian samples examined show that subjectively overqualified people 
compared to employees who had the same qualification as suitably qualified, earn less. On the other hand, there were also differences within the subjectively overqualified group; highly overqualified people earn even less than moderately overqualified people with the same (educational) qualification. It also became clear that overqualified people with higher education or a higher (education) qualification experienced the greatest drop in salaries. In addition to these findings, it appears relevant for the connection between overqualification and salary when overqualification occurs in the professional career. Verbruggen et al., in (2015) examined the impact of objective part of overqualification from a sample of Dutch university graduates, three cohorts were interviewed having one year, five years, and ten years after graduation. This longitudinal study design generally showed that graduates who were overqualified and serving from one year had a lower salary compared to the overqualified graduates five from years. Simultaneously, the impact of overqualification on salary was more significant the later the overqualification occurred with e.g., five years. Büchel and Mertens (2004) to examine the salary growth, conducted a longitudinal study with more than 12,000 participants in Germany and reported that objectively overqualified people are less likely to achieve above-average growth in wages. Similar results can also be seen in similar samples from Great Britain, Spain, and Belgium with objective and subjective measures of overqualification (Alba-Ramirez 1993; Battu et al. 1999; Nabi 2003; Verhaest \& Omey 2006). As mentioned before, promotions were also examined in the context of objective career success indicators. In a study using US panel data for objectively overqualified employees, Sicherman (1991) reported a higher probability of being promoted to a higher position (see also Rubb, 2006). Dekker et al. (2002) also examined the connection between overqualification and career advancement. In this study, a representative sample of Dutch workers was questioned twice every two years. The authors report a positive connection between objective overqualification during measurement and professional advancement outside the company two years later. This finding could be replicated in a Taiwanese panel sample (Hung, 2008); it was even shown here that overqualified people are also promoted more frequently on the internal job market than adequately qualified people.

\section{H1: Overqualification positively impacts the career success.}

\section{Overqualification: The Mediating Effect of Proactive Behavior}

The reported findings on overqualification and or career-related links convey a two-sided picture. On the one hand, overqualified people are less satisfied with their work and tend to be more dissatisfied with their careers. On the other hand, it shows that overqualified people earn more than their direct colleagues in the same position, experience stronger salary increases, and are promoted more frequently. Based on theoretical assumptions and findings on 
proactivity, a framework model for organizational career development in the context of overqualification is outlined, which should integrate these findings (see Fig. 1).

The state of mismatch and dissatisfaction can also motivate individuals to act proactively (e.g., Parker \& Collins, 2010). Proactive behavior helps to make certain changes in himself or the environment (Grant \& Ashford, 2008). For example, in the context of job crafting, a person changes his or her tasks and responsibilities at work and looks for challenging activities like implementing an introductory program for new employees. As a result of these changes in one's role and activities, job crafting can lead to the greater importance of work and satisfaction among employees in the long term (Wrzesniewski \& Dutton, 2001). In addition, overqualified people can increasingly display voice behaviour and they actively approach their superiors and make suggestions for improvements with regard to organizational processes, bring in ideas or initiate new projects (Van Dyne \& LePine, 1998). Both proactive behaviors could have a signal effect (see Bangerter et al., 2012). Relevant decision-makers (e.g., supervisors) are increasingly aware of overqualified people and their hidden potential. Overqualified people are more likely to be promoted than their adequately qualified colleagues at the same job level and receive more salary (e.g., Quintini, 2011; Sicherman, 1991).

Furthermore, it seems plausible that objective career success positively impacts subjective assessments of one's career and can thus counteract the negative effects of de-privatization and mismatch described above. Based on the proactivity literature's theoretical assumptions and findings, we would like to mention two important boundary conditions. People are likely to respond proactively to feelings of deprivation and mismatch when they find a high degree of autonomy in their work (i.e., when they have a lot of freedom to do their work) (Morgeson $\&$ Humphrey, 2006) and when they possess proactive behavior (i.e., if they are "proactive personalities") (Seibert et al., 2001). Although other authors have also discussed proactive behaviour as a possible consequence of overqualification (Liu \& Wang 2012; Russell et al., 2016). Similarly, Zhang et al. (2016) showed that overqualified people show proactive behavior; this connection is mediated by an increase in self-efficacy regarding the execution of a larger area of activity. Proactive behaviour can lead to the career success (e.g., Barthauer et al., 2016). So based on literature and theory it is assumed that:

H2: Proactive behavior mediates the relationship between perceived overqualification and career success.

\section{Overqualification: Mediating Role of Relative Deprivation}

The Study assumes that relative deprivation mediates between the overqualification, and career success based on the assumptions of relative deprivation theory and the PE fit theory. The study believe that these negative experiences are primarily feelings of deprivation and a 
mismatch of needs and offers (Crosby, 1984; Edwards et al., 1998). The P-E fit theory proposes that a mismatch between requirements and qualifications translates directly into a perceived mismatch between needs and offers and these negative emotional states can lead to people becoming relatively dissatisfied with their career (e.g., Harari et al. 2017).

Generally, people give more weightage to their environment and justice perceptions. Research shows that the theory of relative deprivation recommends that deprivation feelings arises from comparing the current states of individuals and their past or future state of mind and also comparing the value ability and expectations (Maynard \& Parfyonova, 2013). Based upon their level of education, skills e and knowledg, people view their jobs as worthless So, they face a psychological conflict in value they expect and the value ability, this situation generates a sense of deprivation in them (Vecchio \& Boatwright, 2002). This research propose that relative deprivation serves as mediator between the relationship of perceived overqualification and career success Past researchers like Feldman in (1996) argued that perceived overqualification negatively impact the employee reactions because it instigate a sense of deprivation in employee about the job currently doing and what they actually deserve. So, on the basis of this, the study propose that:

H3: Relative deprivation mediates the relation of perceived overqualification and career success.

\section{The Need for Achievement as Moderator}

The desire to accomplish demanding and demanding objectives for personal reasons is characterized as an instinctive motivator that motivates individuals to do well or enhance their performance (McClelland, 1987). Individuals who are driven by a strong desire for achievement often exhibit their ability by completing challenging activities while adhering to consistent and higher standards (Schultheiss et al., 2014). Such employees are continually considering rapid feedback in order to enhance their future performance (Boyatzis \& Kolb, 1995). On the other side, those low on need for achievement may be persuaded to retain the status quo, lack the motivation to engage in ambitious objectives, and devote minimum effort to ongoing growth (Loon \& Casimir, 2008). When individuals are placed in a job where the criteria fall short of their abilities, experience, and expertise, they may behave differently based on their desire for accomplishment, and a new work passion may be sparked.

Employees who think they are overqualified do so because their contribution to work and the reward they get from work is uneven (Ryan, 2016). These emotions are compelling in persons who have a great desire to achieve. Overqualified worker having higher need for achievement are more intrinsically motivated to exert their efforts and abilities in completing complex jobs 
and justify the position they hold (Pang, 2010); and they found their job lacking in requirements. Such an incoherent setting will discourage them and sap their harmonized excitement for tasks (e.g., Luksyte et al., 2011). Employees having overqualification with a strong drive for accomplishment may be more susceptible to this kind of mismatch in workers and job (i.e., overqualification); consequently, they may experience a decline in harmonic love for tasks assigned to them. Moreover, overqualified personnel with a strong desire for accomplishment will have more extreme sentiments of injustice since the assigned work to them is much below the talents they have.

As a consequence of their frustration with their inability to succeed, individuals are more prone to have low harmonious passion. On the other side, overqualified personnel with low demand for accomplishment lack the drive to engage in their job and perpetuate the status quo. Consequently, they are mostly unaffected by a mismatch between the person and work and will not necessarily have less harmonic enthusiasm. For example, employees with low demand for accomplishment may not be sensitive towards losses their amicable passion in a POQ setting due to their perception of less unfairness in their existing employment. As a consequence, they are less prone to exhibit less harmonious passion in response. Accordingly, the study proposes the following hypothesis:

H4(a) Need for achievement serves as moderator between the relation of perceived overqualification and Proactive behavior in a way that the positive relation becomes more stronger for employees having a high need for achievement.

$\boldsymbol{H} 4(\boldsymbol{b})$ Need for achievement serves as moderator between the relation of perceived overqualification and relative deprivation in a way that the relation is weaker when employees have a high need for achievement.

\section{THEORETICAL FRAMEWORK}

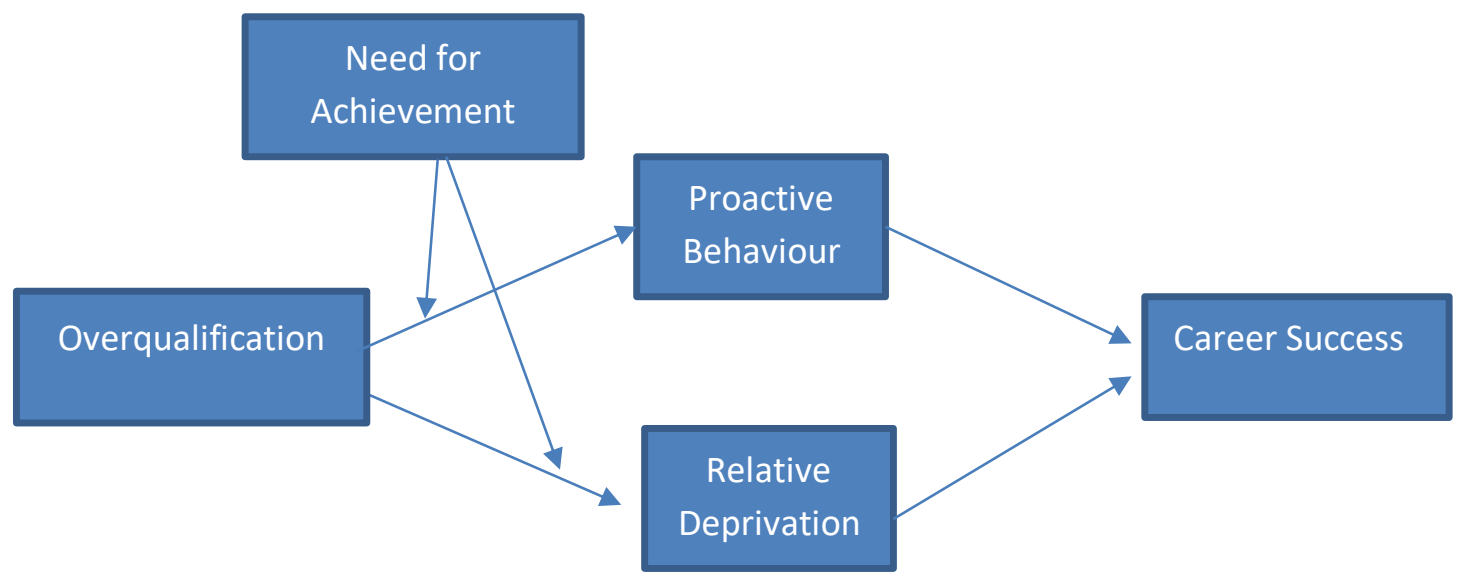

Figure 1.Theoretical Model 


\section{Sample and Procedures}

\section{METHODOLOGY}

Data was gathered in three phases from the universities of Lahore and Faisalabad, Pakistan, which aided in reducing any standard technique discrepancies (Podsakoff et al., 2003). Respondents were questioned about their POQ levels, achievement needs, and demographic information in the initial wave of surveys (T1). Two months later, in a second poll (T2), individuals reported their proactive behavior and relative deprivation. Respondents were asked to estimate their career success in the third poll (T3). The researchers guaranteed that the same participant received the three-stage survey using the name list and the personnel officer's coding method. In the first set of surveys, 456 questionnaires were returned, yielding an 85.23 percent response rate. Three hundred eighty-two questionnaires were returned in the second round of surveys, yielding an 83.77 percent response rate. In the third round of surveys, 318 questionnaires were received, accounting for 83.25 percent of the total.

All 318 respondents were included in our final sample. 60.4 percent of the 318 responders were male. They are diverse in age, with $49.7 \%$ of participants between the ages of 26 and 35 . In terms of educational attainment, 4.03 percent of respondents have completed high school, 35.80 percent have earned a bachelor's degree, and 60.27 percent have earned a master's or Ph.D.

\section{Measures}

In addition, to ensure the accuracy of all research instruments, we pre-tested a small number of civil servants for all projects based on the recommendations of Schaffer and Riordan (2003). Respondents responded with a five-point Likert scale from 1 (strongly disagree) to 5 (strongly agree).

\section{Perceived Over Qualification (POQ)}

The study utilized a nine-item scale created by Maynard et al. (2006) to assess workers' assessments of their academic credentials, skills, talents, training, and work experience in addition to job requirements. "My ability surpasses what I need to do the work" is an example project with a Cronbach's alpha of 0.75 .

\section{Need for Achievement}

To measure employee need for achievement, a seven-item scale developed by Steers and Braunstein (1976) was used. A sample item was "I do my best work when my job assignments are fairly difficult". Cronbach's alpha was 0.71 .

\section{Proactive Behavior}

The study examined self-reported and supervisor-reported proactive behavior (i.e., taking the initiative and taking control) using 5-point Likert scales ranging from 1 (complete agreement) 
to 5 (complete disagreement) (fully agree). We quantified personal initiative using Frese, Fay, Hilburger, Leng, and Tag's seven-item scale (1997). "I aggressively attack problems" is an example item for self-ratings, while "He/she aggressively attacks problems" is a sample item for supervisor ratings. Cronbach's alphas for self-evaluations were.77, and for supervisor ratings were.89. Research judged taking responsibility using six elements from the Morrison and Phelps scale (1999). For self-ratings, a typical question is "I often attempt to improve processes for the work unit or department," and for supervisor ratings, "He/she often attempts to improve procedures for the work unit or department." Cronbach's alphas for self-evaluations were 0.90 , and supervisor ratings were 0.93 , respectively.

\section{Relative Deprivation}

The study used a 5-item Relative Deprivation Scale developed by Callan, Shead, and Olson (2011).

\section{Career Success}

In this research, career success is measured using Hinkin and Tracey's (1999) 24 items measure. The research uses a seven-point Likert scale rating (1 to 7) to measure career success and develop a scale score. The scale examines that career success is described as an individual's judgments and ability based on their perceptions to investigate the different practices and individuals toward their profession. This scale is a self-perceived measure of career success and outcomes toward employee career. The internal consistency value described by the researcher on this measure ranges from 0.87 (Hinkin \& Tracey, 1999). In the present study, internal consistency was 0.86 . The total score is calculated by finding the sum of all items with a higher score indicating higher career success. The coefficient alpha of this research was 0.82 .

\section{Control Variables}

Based on previous study conducted by Lim and Chen (2012), the study selected age, gender, employees' tenure, and education as control variables in the study.

\section{RESULTS}

\section{Non-Response and Common Method Biases}

In accordance with Armstrong and Overton's (1977) guidelines, we investigated non-response bias in order to increase the study's efficacy. The results shows no statistical differences between these factors $(p>0.05)$, which casts doubt on our conclusions. Furthermore, since these control variables are self-reported, our research may be influenced by method bias in general (Podsakoff et al., 2003). Harman (1976) recommended that we used a single factor test to assess the possible severity of general technique bias. The eigenvalues of all six factors are larger than one, and the first component explains 23.16 percent of the variation. Given that the first component contributes just a tiny portion of the overall variation and other components 
emerge in our investigation, the general method's bias does not seem to be a significant issue (Podsakoff et al., 2003).

Means, standard deviations, and correlation coefficients for the research variables are shown in Table 1. We did a confirmatory factor analysis to demonstrate the validity of our hypothetical assessment model since we examined perceived overqualification, proactive behavior, relative deprivation, and professional success. We defined four first-order and one second-order empowerment variables (Spreitzer, post-1995) and variables for perceived overqualification, proactive behavior, relative deprivation of professional success, and desire for accomplishment. We designed each object in such a way that it could be loaded into a single factor and permitted

Table 1. Means, Standard Deviations, and Intercorrelations Among Variables

\begin{tabular}{|c|c|c|c|c|c|c|c|c|c|c|c|c|c|}
\hline Variable & $M$ & $S D$ & 1 & 2 & 3 & 4 & 5 & 6 & 7 & 8 & 9 & $\mathbf{1 0}$ & 11 \\
\hline 1.Perceived POQ & 4.35 & 1.35 & - & & & & & & & & & & \\
\hline 2. Career success & 5.80 & 0.86 & $-.19^{* *}$ & - & & & & & & & & & \\
\hline 3. Proactive behaviour & 4.77 & 1.61 & $-.21^{* *}$ & $.51^{* *}$ & - & & & & & & & & \\
\hline 4. Relative deprivation & 0.18 & 0.39 & .09 & -.06 & -.09 & - & & & & & & & \\
\hline 5. Need for achievement & 5.42 & 0.72 & .03 & $.43^{* *}$ & $.29^{* * *}$ & -.08 & - & & & & & & \\
\hline 6. Age & 23.70 & 55.01 & -.11 & .02 & .00 & .04 & $.20^{* *}$ & - & & & & & \\
\hline 7. Gender: Male & 60.04 & 2.47 & $.22^{* *}$ & -.11 & -.04 & .05 & .07 & $.16^{*}$ & - & & & & \\
\hline 8. Organizational tenure & 13.52 & 11.69 & -.02 & .01 & .05 & -.04 & $.28^{* *}$ & $.21^{* *}$ & $.39^{* *}$ & - & & & \\
\hline 9. University graduate & 60.27 & 0.48 & $.16^{*}$ & $-.16^{*}$ & $-.13^{*}$ & .04 & -.04 & -.03 & .08 & .02 & - & & \\
\hline 10. College graduate & 35.80 & 0.44 & .05 & -.03 & -.04 & .00 & -.01 & -.01 & -.04 & .02 & $-.45^{* *}$ & - & \\
\hline 11. High school graduate & 0.403 & 0.48 & $-.21^{* *}$ & $.18^{* *}$ & $.17^{* *}$ & -.04 & .05 & .04 & -.05 & -.04 & $-.58^{* *}$ & $-.47^{* *}$ & - \\
\hline
\end{tabular}

H1 investigated the direct link between over-qualification and career success and discovered a statistically significant direct link between the two variables $(B=0.182 ; t=2.146)$ with an $R 2$ value of 0.671 . $\mathrm{H} 2$ examines the role of proactive behaviour as mediator among overqualification and career success. Through proactive behaviour, overqualification has a substantial indirect effect on career success (p0.05). H3 examines the mediating influence of relative deprivation on the connection between job success and overqualification. Through relative deprivation, the indirect effect of overqualification on job performance was shown to be significant (p0.05). Following the Zhou, Li, and Gong, (2019), the primary objective of this comparison is to ascertain whether the significance of indirect path through proactive behaviour and relative deprivation will diminish the significance of the direct path between overqualification and career success and become insignificant in the presence of mediator. The findings indicate that, in comparison to the direct model between overqualification and career success $(0.692)$, the value is much lower in the mediation model at 0.470 for proactive behavior and 0.499 for relative deprivation. As a result, a function of partial mediation has been identified, as seen in Table 2. 
Table 2. Mediation Results of Proactive Behaviour and Relative Deprivation between Overqualification and Career Success

\begin{tabular}{lllllll}
\hline \multicolumn{1}{c}{ Construct } & Estimate & S.E. & $\boldsymbol{\beta}$ & $\mathbf{t}$ & $\boldsymbol{R}^{\mathbf{2}}$ & $\boldsymbol{p}$ \\
\hline $\begin{array}{l}\text { Direct Model } \\
\mathrm{OQ} \rightarrow \mathrm{CS}\end{array}$ & 0.667 & 0.144 & 0.692 & 4.624 & 0.671 & .000 \\
$\begin{array}{l}\text { Mediation Model-1 } \\
\mathrm{OQ} \rightarrow \mathrm{PB}\end{array}$ & 0.877 & 0.196 & 0.470 & 4.480 & 0.428 & .000 \\
$\mathrm{~PB} \rightarrow \mathrm{CS}$ & 0.201 & 0.038 & 0.398 & 5.236 & 0.437 & .000 \\
Mediation Model-2 & & & & & & \\
$\mathrm{OQ} \rightarrow \mathrm{PB}$ & 0.469 & 0.110 & 0.499 & 15.501 & 0.651 & .000 \\
$\mathrm{~PB} \rightarrow \mathrm{CS}$ & 0.578 & 0.182 & 0.661 & 10.834 & 0.437 & .000 \\
\hline
\end{tabular}

Notes: Estimate $=$ regression weight; S.E. $=$ standard error; $\beta=$ standardized regression weights; $C . R .=$ critical ratio; $p=p<.05 .{ }^{* *} p<.01 . O Q=$ overqualification $C S=$ career success, $P B=$ proactive behavior, $R D=$ Relative Deprivation

To examine the moderating effect of overqualification and proactive behavior ( $\mathrm{H} 4 \mathrm{a})$ and overqualification and relative deprivation $(\mathrm{H} 4 \mathrm{~b})$, we used the hierarchical linear modeling technique recommended by Cohen et al. (2003) for comparable models.

Table 3. Results of Regression Model showing the Moderating relation of Need for Achievement for Proactive Behavior, and Relative Deprivation

\begin{tabular}{|c|c|c|c|c|c|c|}
\hline & \multicolumn{5}{|c|}{ Proactive Behavior } & \multirow{2}{*}{$\frac{\text { Relative Deprivation }}{t}$} \\
\hline Variable & Estimate & $S E$ & $t$ & Estimate & $S E$ & \\
\hline \multicolumn{7}{|l|}{ Level 1} \\
\hline \multicolumn{7}{|l|}{ Intercept $\left(3_{0}\right.$} \\
\hline Intercept - $\mathrm{y}_{00}$ & 5.83 & 0.05 & $110.70^{* *}$ & 4.54 & 0.11 & $41.06^{* *}$ \\
\hline \multicolumn{7}{|l|}{ Genger: Male $\left(3_{1}\right.$} \\
\hline Intercept - $y_{10}$ & -0.00 & 0.00 & -1.30 & -0.01 & 0.00 & $-3.63 *$ \\
\hline \multicolumn{7}{|l|}{ Age $\left(3_{2}\right.$} \\
\hline Intercept -y20 & -0.02 & 0.01 & -0.17 & -0.03 & 0.04 & -0.11 \\
\hline \multicolumn{7}{|l|}{ Organizational tenure $\left(3_{3}\right.$} \\
\hline Intercept $-y_{30}$ & -0.12 & 0.06 & -1.82 & -0.01 & 0.03 & -2.73 \\
\hline \multicolumn{7}{|l|}{ College graduate $\left(3_{4}\right.$} \\
\hline Intercept -y40 & -0.23 & 0.11 & -2.01 & -0.30 & 0.11 & -1.05 \\
\hline \multicolumn{7}{|l|}{ College student $(35$} \\
\hline Intercept $-\mathrm{y}_{50}$ & -0.25 & 0.09 & $-2.85^{* *}$ & -0.29 & 0.06 & -1.65 \\
\hline \multicolumn{7}{|l|}{ Perceived overqualification $(36$} \\
\hline Intercept -y 60 & -0.08 & 0.03 & $-2.39 * *$ & -0.22 & 0.02 & -2.59 \\
\hline \multicolumn{7}{|l|}{ Proactive Behaviour ( 37} \\
\hline Intercept -y70 & 0.56 & 0.09 & $6.14 * * *$ & 0.67 & 0.05 & $5.31^{*}$ \\
\hline \multicolumn{7}{|l|}{ Overqualification X Proactive Behaviour( 38} \\
\hline Intercept -y80 & 0.11 & 0.05 & $2.29 *$ & 0.29 & 0.06 & $3.26 * *$ \\
\hline Perceived overqualification $(36$ & 17.02 & 7.60 & $2.24 *$ & 11.11 & 6.50 & $4.29 * *$ \\
\hline \multicolumn{7}{|l|}{ Intercept $-\mathrm{y}_{60}$} \\
\hline Relative Deprivation $(37$ & 27.00 & $\begin{array}{c}10.0 \\
2\end{array}$ & $2.64 *$ & 23.00 & 12.03 & $2.66^{*}$ \\
\hline \multicolumn{7}{|l|}{ Intercept -y70 } \\
\hline $\begin{array}{l}\text { Overqualification X Relative Deprivation }(38 \\
\text { Intercept -y } 80\end{array}$ & 10.42 & 7.31 & $2.44 * *$ & 9.33 & 5.23 & $3.14 * *$ \\
\hline Model $R^{2}$ & & .47 & & & .34 & \\
\hline$* R^{2}$ & & .05 & & & .05 & \\
\hline
\end{tabular}

Estimate SE t Estimate SE $t$ Estimate SE $t$

Note. $N=318$ Model $R^{2}$ is the proportional reduction in the Level 1 variance component (see Hofmann, 1997). $* R^{2}$ is the increase in $R^{2}$ when the interaction term was entered in a separate step. $p<.05 . p<.01$.

As Hypothesis 4(a) predicts, the link between perceived overqualification and proactive behavior is moderated by the need for achievement. As shown in Table 3, the interaction term 
of felt overqualification and felt desire for accomplishment was significant in terms of proactive behavior. We graphed the connection between high and low attainment requirements (defined as one standard deviation above and below the mean). Figure 1 depicts the plot. Simple slope analyses revealed that perceived overqualification was adversely connected to proactive activity at low levels of need for accomplishment $(=0.11, \mathrm{SE}=0.05 ; \mathrm{t}=2.29, \mathrm{p}=.01)$, but a high degree of need for accomplishment positively correlates with proactive activity. These findings corroborate the 4 (a). According to hypothesis 4(b), the urge for accomplishment acts as a mediator between overqualification and relative disadvantage. The findings indicate that a low level of accomplishment need is favourably connected to relative deprivation, but a high achievement need is negatively associated with relative deprivation, supporting hypothesis 4 (b).

\section{DISCUSSION}

This study contributed to the existing literature on over-qualification by using proactive behavior and relative deprivation as a mediator between perceived overqualification and career success. The study introduces the need for achievement as a moderator between overqualification and proactive behavior and relative deprivation. The results confirmed that perceived overqualification is positively related to career success. Proactive behavior and relative deprivation mediate between overqualification and career success. Moreover, the findings suggest that a high need for achievement strengthens the positive relationship between perceived overqualifications and proactive behavior, whereas a high need for achievement weakens the relationship between perceived overqualification and relative deprivation. These findings show that employees high on need for achievement will show more proactive behavior with overqualification and low relative deprivation. The results are consistent with previous studies (e.g., Hung 2008; Barthauer et al., 2016; Feldman 1996; Ryan 2016).

In the previous explanations, we implicitly assumed that HR managers and supervisors know which people are overqualified. In contrast to the definition of overqualification, which is widespread in psychology, as too much experience, knowledge and (training) level, the two interview studies mentioned above (Kulkarni et al. 2015; Maynard et al. 2009) show that HR managers are overqualified typically identify based on the (training) level of education compared to the (training) level required for the position. Therefore, the idea of overqualification is similar to organizational decision-makers from the above-mentioned objective view or operationalization. Accordingly, it seems plausible that employees and superiors will not necessarily come to the same assessment of whether a person is overqualified or not. For example, it could be that a person's (educational) level of education is significantly above the level necessary for the job. Under certain circumstances, however, such a person 
would not perceive himself as overqualified due to his work requirements if he perceived them to be rather challenging (e.g., a university graduate who works as a waitress in a bar but no experience with constant customer contact and the correct taking of orders at high noise levels). Conversely, an HR specialist could feel overqualified in her new position in a medium-sized company despite the appropriate training level since she was entrusted with many strategic tasks at her old employer that did not exist in the new position.

Based on our model, superiors must recognize perceived overqualification signals on the part of employees. Regular employee interviews can be used, for example, to determine whether a person feels deprived. In addition, superiors should try to find out from which motivation these behaviors are shown and bear in mind that overqualification can be a reason for proactive behavior. If this is the case, it is obvious that particularly overqualified persons can benefit from a promotion or a change of job in terms of their satisfaction, and organizations can thus exploit the previously untapped potential of these employees.

\section{MANAGERIAL IMPLICATIONS}

In a qualitative interview study, Maynard, Taylor, and Hakel (2009) showed that HR managers view overqualification as a primarily negative phenomenon. Respondents indicated that overqualified employees are likely to be arrogant and less easy to manage. A recently published interview study, which was also carried out with HR managers, provides a more balanced picture (Kulkarni et al., 2015). The respondents again assumed that overqualified people could be bored, arrogant, and frustrated. Nevertheless, 20 of the 24 respondents indicated that they would generally hire overqualified people since they represent essential human capital and bring a "fresh breeze" into the organization. The authors also point out that employment of overqualified persons is particularly worthwhile if it is employment "for the organization" (instead of employment for a specific position), i. H. if there are internal career opportunities that could be considered overqualified candidates. The study by Kulkarni et al. (2015) clarifies that the attitudes of HR managers regarding the employment of overqualified persons have changed and that overqualification can even be a competitive advantage for a company. In line with our previously developed model of overqualification in the context of career development, we will show below how organizations can use the potential of their overqualified employees and thus be an attractive employer for this group of people.

Organizational contextual conditions can play a crucial role in determining whether overqualification is viewed as a negative phenomenon by those affected. Wu et al. (2015) confirmed the motivating role of autonomy in their study. The authors showed that subjective overqualification is only negatively associated with well-being if those affected experience a 
low level of autonomy in their work (see also the role of autonomy in the model described above). Similar results were shown in another study regarding adaptive performance (Wu et al., 2017). Using the related construct of empowerment (eng. Empowerment, i.e., transferring responsibility), Erdogan and Bauer (2009) showed that subjectively overqualified people, who feel empowered, have no loss of job satisfaction and no increased intentions to change, and indeed do not leave the company more often. These findings clarify that organizations with autonomy can design an important work feature themselves to contain the potentially negative effects of overqualification. Therefore, it is advisable to view job descriptions as less rigid (cf. Russell et al., 2016) and give (particularly overqualified) employees freedom to carry out their work. In addition to its motivating quality, autonomy is also a key driver for proactive behavior, through which people can design their work contents according to their needs (Leana et al., 2009). Moreover, proactive employees can be profitable from an organizational point of view (regardless of the topic of overqualification) since there are meta-analytically positive connections between proactivity and work performance (Thomas et al., 2010).

\section{CONCLUSION}

The present article shows that (especially perceived) overqualification with regard to attitude and situation-related correlates is a precarious situation. Nevertheless, overqualification in terms of the career development of those affected is not per se an obstacle. Through their experience and proactive behavior, overqualified people can represent a valuable asset for their organizations, which must also be properly promoted from an organizational perspective. Organizations can promote their overqualified employees is to assign challenging tasks explicitly. Although there are no empirical findings in the context of overqualification, such a measure would be in line with the classic approach of job enrichment, i.e., people are given additional tasks that exceed the previous level of requirements (e.g., Parker, 1998). When purchasing a new product category, an overqualified person who is primarily responsible for writing invoices in the purchasing area, for example, could also be given the task of researching possible suppliers and selecting them accordingly. As part of the job enrichment, there is also the possibility of assigning a mentor role to overqualified people (e.g., for newcomers), through which they can pass on existing knowledge and experience and have the opportunity of taking more responsibility in the company (cf. Luksyte \& Spitzmüller, 2016). 


\section{REFERENCES}

Alba-Ramirez, A. (1993). Mismatch in the Spanish labor market: over- education. Journal of Human Resources, 28, 259-278. https://doi. org/10.2307/146203.

Armstrong, J. S., \& Overton, T. S. (1977). Estimating nonresponse bias in mail surveys. Journal of marketing research, 14(3), 396-402.

Arthur, M. B., Khapova, S. N., \& Wilderom, C. P. M. (2005). Career success in a boundaryless career world. Journal of Organizatio- nal Behavior, 26, 177-202. https://doi.org/10.1002/job.290.

Bangerter, A., Roulin, N., \& König, C. J. (2012). Personnel selectionas a signaling game. Journal of Applied Psychology, 97, 719-738. https://doi.org/10.1037/a0026078.

Barthauer, L., Estel, V., Dubbel, A., Kauffeld, S., \& Spurk, D. (2016). Woran erkenne ich eine erfolgreiche Laufbahn? Ein qualitativer Ansatz zur Definition von Laufbahnerfolg bei Wissenschaftlern. Beiträge zur Hochschulforschung, 38, 42-63.

Battu, H., Belfield, C. R., \& Sloane, P. J. (1999). Overeducation among graduates: a cohort view. Education Economics, 7, 21-38. https:// doi.org/10.1080/09645299900000002.

Boyatzis, R. E., \& Kolb, D. A. (1995). From learning styles to learning skills: the executive skills profile. Journal of managerial psychology.

Büchel, F. (2001). Overqualification: Reasons, measurement issues and typological affinity to unemployment. In P. Descy \& M. Tessa- ring (Hrsg.), Training in Europe: Second report on vocational training research in Europe 2000 (background report) (Band 2, S. 453-560). Luxembourg: Office for Official Publications of the European Communities.

Büchel, F., \& Mertens, A. (2004). Overeducation, undereducation, and the theory of career mobility. Applied Economics, 36, 803-816. https://doi.org/10.1080/0003684042000229532.

Callan, M. J., Shead, N. W., \& Olson, J. M. (2011). Personal relative deprivation, delay discounting, and gambling. Journal of personality and social psychology, 101(5), 955.

Crosby, F. (1984). Relative deprivation in organizational settings. In B. M. Staw \& L. L. Cummings (Hrsg.), Research in organizatio- nal behavior (Bd. 6, S. 51-93). Greenwich: JAI Press.

Dekker, R., de Grip, A., \& Heijke, H. (2002). The effects of training and overeducation on career mobility in a segmented labour mar- ket. International Journal of Manpower, 23, 106-125. https://doi. org/10.1108/01437720210428379.

Edwards, J. R. (1996). An examination of competing versions of the person-environment fit approach to stress. Academy of Manage- ment Journal, 39, 292-339. https://doi.org/10.2307/256782. 
Edwards, J. R., Caplan, R. D., \& Van Harrison, R. (1998). Person-environment fit theory: conceptual foundations, empirical evidence, and directions for future research. In C. L. Cooper (Hrsg.), Theo- ries of organization stress. Oxford: Oxford University Press.

Erdogan, B., \& Bauer, T. N. (2009). Perceived overqualification and its outcomes: the moderating role of empowerment. Journal of App-lied Psychology, 94, 557-565. https://doi.org/10.1037/a0013528.

Erdogan, B., \& Bauer, T. N. (2021). Overqualification at work: a review and synthesis of the literature. Annual Review of Organizational Psychology and Organizational Behavior, 8, 259-283.

Erdogan, B., Bauer, T. N., Peiró, J. M., \& Truxillo, D. M. (2011). Over-qualified employees: making the best of a potentially bad situati- on for individuals and organizations. Industrial and Organizatio- nal Psychology, 4, 215-232. https://doi.org/10.1111/j.17549434. 2011.01330.x.

Feldman, D. C. (1996). The nature, antecedents and consequences of underemployment. Journal of management, 22(3), 385-407.

Frese, M., Fay, D., Hilburger, T., Leng, K., \& Tag, A. (1997). The concept of personal initiative: Operationalization, reliability and validity in two German samples. Journal of occupational and organizational psychology, 70(2), 139-161.

Grant, A. M., \& Ashford, S. J. (2008). The dynamics of proactivity at work. Research in Organizational Behavior, 28, 3-34. https://doi. org/10.1016/j.riob.2008.04.002.

Harari, M. B., Manapragada, A., \& Viswesvaran, C. (2017). Who thinks they're a big fish in a small pond and why does it matter? A meta-analysis of perceived overqualification. Journal of Voca- tional Behavior, 102, 28-47. https://doi.org/10.1016/j.jvb.2017.06.002.

Harman, H. H. (1976). Modern factor analysis. University of Chicago press.

Heslin, P. A. (2005). Conceptualizing and evaluating career success. Journal of Organizational Behavior, 26, 113-136. https://doi.org/ 10.1002/job.270.

Hinkin, T. R., \& Tracey, J. B. (1999). An analysis of variance approach to content validation. Organizational Research Methods, 2(2), 175-186.

Howard, E., Luksyte, A., Amarnani, R. K., \& Spitzmueller, C. (2021). Perceived overqualification and experiences of incivility: Can task i-deals help or hurt? Journal of occupational health psychology.

Hung, C.-Y. (2008). Overeducation and undereducation in Taiwan. Journal of Asian Economics, 19, 125-137. https://doi.org/10. 1016/j.asieco.2008.02.001. 
Kristof-Brown, A. L., Zimmerman, R. D., \& Johnson, E. C. (2005). Consequences of individuals' fit at work: a meta-analysis of person-job, person-organization, persongroup, and person-su- pervisor fit. Personnel Psychology, 58, 281-342. https://doi.org/ 10.1111/j.1744-6570.2005.00672.x.

Kulkarni, M., Lengnick-Hall, M. L., \& Martinez, P. G. (2015). Over-qualification, mismatched qualification, and hiring decisions: per- ceptions of employers. Personnel Review, 44, 529-549. https:// doi.org/10.1108/Pr-11-2013-0204.

Leana, C., Appelbaum, E., \& Shevchuk, I. (2009). Work process and quality of care in early childhood education: the role of job craf- ting. Academy of Management Journal, 52, 1169-1192. https:// doi.org/10.5465/AMJ.2009.47084651.

Lee, C. H. (2005). A study of underemployment among self-initiated expatriates. Journal of World Business, 40, 172-187. https://doi. org/10.1016/j.jwb.2005.02.005

Liu, S., \& Wang, M. (2012). Perceived overqualification: a review and recommendations for research and practice. In P. L. Perrewé,

Loon, M., \& Casimir, G. (2008). Job-demand for learning and job-related learning: The moderating effect of need for achievement. Journal of Managerial Psychology.

Luksyte, A., Spitzmueller, C., \& Maynard, D. C. (2011). Why do overqualified incumbents deviate? Examining multiple mediators. Journal of occupational health psychology, 16(3), 279.

Luksyte, A., \& Spitzmüller, C. (2016). When are overqualified em-ployees creative? It depends on contextual factors. Journal of Or- ganizational Behavior, 37, 635-653. https://doi.org/10.1002/job.2054.

Mavromaras, K., McGuinness, S., O’Leary, N., Sloane, P., \& Fok, Y. K. (2010). The problem of overskilling in Australia and Bri- tain. Manchester School, 78, 219-241. https://doi.org/10.1111/j.1467-9957.2009.02136.x.

Maynard D C, Parfyonova N M. (2013). Perceived Over-qualification and Withdrawal Behaviours: Examining the Roles of Job Attitudes and work values . Journal of Occupational and Organizational Psychology, 86(3):435-455.

Maynard, D. C., Joseph, T. A., \& Maynard, A. M. (2006). Underem-ployment, job attitudes, and turnover intentions. Journal of Or- ganizational Behavior, 27, 509-536. https://doi.org/10.1002/Job.389.

Maynard, D. C., Taylor, E. B., \& Hakel, M. D. (2009). Applicant over- qualification: perceptions, predictions, and policies of hiring ma- nagers. In O. T. Chen (Hrsg.), Organizational behavior and dyna-mics (S. 13-38). Hauppauge: Nova Science.

McGuinness, S. (2006). Overeducation in the labour market. Journal of Economic Surveys, 20, 387-418. https://doi.org/10.1111/j.0950- 0804.2006.00284.x. 
McClelland, D. C. (1987). Human motivation. CUP Archive.

Morgeson, F. P., \& Humphrey, S. E. (2006). The Work Design Ques-tionnaire (WDQ): developing and validating a comprehensive measure for assessing job design and the nature of work. Journal of Applied Psychology, 91, 1321-1339. https://doi.org/10.1037/0021-9010.91.6.1321.

Nabi, G. R. (2003). Graduate employment and underemployment: op- portunity for skill use and career experiences amongst recent busi- ness graduates. Education + Training, 45, 371-382. https://doi. org/10.1108/00400910310499947.

Ng, T. W. H., Eby, L. T., Sorensen, K. L., \& Feldman, D. C. (2005). Pre-dictors of objective and subjective career success: a meta-analy- sis. Personnel Psychology, 58, 367-408. https://doi.org/10.1111/j.1744-6570.2005.00515.x.

OECD Stat. (2021). Retrieved from https://stats.oecd.org/Index.aspx

Pang, J. S. (2010). The achievement motive: A review of theory and assessment of $n$ achievement, hope of success, and fear of failure. Implicit motives, 1, 30-71.

Parker, S. K. (1998). Enhancing role breadth self-efficacy: the roles of job enrichment and other organizational interventions. Journal of Applied Psychology, 83, 835-852. https://doi.org/10.1037/0021-9010.83.6.835.

Parker, S. K., \& Collins, C. G. (2010). Taking stock: integrating and differentiating multiple proactive behaviors. Journal of Manage- ment, 36, 633-662. https://doi.org/10.1177/0149206308321554.

Podsakoff, P. M., MacKenzie, S. B., Lee, J. Y., \& Podsakoff, N. P. (2003). Common method biases in behavioral research: a critical review of the literature and recommended remedies. Journal of applied psychology, 88(5), 879.

Quintini, G. (2011). Over-qualified or under-skilled: a review of exis-ting literature. Paris: OECD Publishing. https://doi.org/10.1787/ 5kg58j9d7b6d-en.

Rubb, S. (2006). Educational mismatches and earnings: extensions of occupational mobility theory and evidence of human capital de- preciation. Education Economics, 14, 135154. https://doi.org/10. 1080/09645290600622905.

Rudolph, C. W., Allan, B., Clark, M., Hertel, G., Hirschi, A., Kunze, F., ... \& Zacher, H. (2021). Pandemics: Implications for research and practice in industrial and organizational psychology. Industrial and Organizational Psychology, 14(1-2), 1-35.

Russell, Z. A., Ferris, G. R., Thompson, K. W., \& Sikora, D. M. (2016). Overqualified human resources, career development experiences, and work outcomes: leveraging an underutilized resource with po- litical skill. Human Resource Management Review, 26, 125-135. https://doi.org/10.1016/j.hrmr.2015.09.008. 
Ryan, J. C. (2016). Old knowledge for new impacts: Equity theory and workforce nationalization. Journal of Business Research, 69(5), 1587-1592.

Schaffer, B. S., \& Riordan, C. M. (2003). A review of cross-cultural methodologies for organizational research: A best-practices approach. Organizational research methods, $6(2), 169-215$.

Schultheiss, O. C., Wiemers, U. S., \& Wolf, O. T. (2014). Implicit need for achievement predicts attenuated cortisol responses to difficult tasks. Journal of Research in Personality, 48, 84-92.

Seibert, S. E., Kraimer, M. L., \& Crant, J. M. (2001). What do proactive people do? A longitudinal model linking proactive personality and career success. Personnel Psychology, 54, 845-874. https://doi. org/10.1111/j.1744-6570.2001.tb00234.x.

Sicherman, N. (1991). Overeducation in the labor market. Journal of Labor Economics, 9, 101-122. https://doi.org/10.1086/298261.

Steers, R. M., \& Braunstein, D. N. (1976). A behaviorally-based measure of manifest needs in work settings. Journal of Vocational behavior, 9(2), 251-266.

Thomas, J. P., Whitman, D. S., \& Viswesvaran, C. (2010). Employee proactivity in organizations: a comparative meta-analysis of emergent proactive constructs. Journal of Occupational and Or- ganizational Psychology, 83, 275-300. https://doi.org/10.1348/ 096317910x502359.

Van Dyne, L., \& LePine, J. A. (1998). Helping and voice extra-role behaviors: evidence of construct and predictive validity. Acade- my of Management Journal, 41, 108-119. https://doi.org/10.2307/ 256902.

Van Harrison, R. (1978). Person-environment fit and job stress. In C. L. Cooper \& R. Payne (Hrsg.), Stress at work (S. 175-205). New York: Wiley.

Vecchio R. P., \& Boatwright K. J. (2002). Preferences for Idealized Styles of Supervision. Leadership Quarterly, 13(4):327-342.

Verbruggen, M., van Emmerik, H., Van Gils, A., Meng, C., \& de Grip, A. (2015). Does earlycareer underemployment impact future career success? A path dependency perspective. Journal of Voca- tional Behavior, 90, 101-110. https://doi.org/10.1016/j.jvb.2015. 08.002 .

Verhaest, D., \& Omey, E. (2006). The impact of overeducation and its measurement. Social Indicators Research, 77, 419-448. https:// doi.org/10.1007/s11205-005-4276-6.

Wrzesniewski, A., \& Dutton, J. E. (2001). Crafting a job: revisioning employees as active crafters of their work. Academy of Management Review, 26, 179-201. https://doi.org/10.2307/259118. 
Wu, C. H., Luksyte, A., \& Parker, S. K. (2015). Overqualification and subjective well-being at work: the moderating role of job autonomy and culture. Social Indicators Research, 121, 917-937. https:// doi.org/10.1007/s11205-014-0662-2.

Wu, C. H., Tian, A. W., Luksyte, A., \& Spitzmueller, C. (2017). On the association between perceived overqualification and adaptive behavior. Personnel Review, 46, 339-354. https://doi.org/10.1108/ Pr-05-2015-0134.

Zhang, M. J., Law, K. S., \& Lin, B. (2016). You think you are big fish in a small pond? Perceived overqualification, goal orientations, and proactivity at work. Journal of Organizational Behavior, 37, 61-84. https://doi.org/10.1002/job.2024.

Zhou, Q., Li, Q., \& Gong, S. (2019). How job autonomy promotes employee's sustainable development? A moderated mediation model. Sustainability, 11(22), 6445. 